\title{
Systemic Adrenocorticotropic Hormone Administration Down-Regulates the Expression of Corticotropin-Releasing Hormone (CRH) and CRH-Binding Protein in Infant Rat Hippocampus
}

\author{
WEI WANG, BRIDGID MURPHY, KIMBERLY E. DOW, R. DAVID ANDREW, AND \\ DOUGLAS D. FRASER

\begin{abstract}
Department of Paediatrics [W.W., K.E.D.], Kingston General Hospital, Queen's University, Kingston, Ontario, Canada, K7L 1N6; Department of Anatomy and Cell Biology [B.M., R.D.A.], Botterell Hall

Queen's University, Kingston, Ontario, Canada, K7L 3N6; Department of Paediatrics and Clinical Group, Canadian Paediatric Epilepsy Network (CPEN)
\end{abstract} \\ Neurological Sciences [D.D.F.], Children's Hospital of Western Ontario, London, Ontario Canada, N6C \\ 2V5; Child Health Research Institute [D.D.F.], London, Ontario, Canada, N6C 2V5; and Clinical Trials
}

\begin{abstract}
Systemic adrenocorticotropic hormone (ACTH) administration is a first-line therapy for the treatment of infantile spasms, an age-specific seizure disorder of infancy. It is proposed that exogenous ACTH acts via negative feedback to suppress the synthesis of corticotropin-releasing hormone (CRH), a possible endogenous convulsant in infant brain tissue. The aim of this study was to determine whether systemic ACTH treatment in infant rats down-regulates the hippocampal CRH system, including $\mathrm{CRH}$, CRH-binding protein (CRH-BP), and $\mathrm{CRH}$ receptors (CRH-R1 and CRH-R2). Daily i.p. injection of ACTH for 7 consecutive days (postnatal days 3-9) elevated serum corticosterone levels 20 -fold measured on postnatal day 10, indicating systemic absorption and circulation of the ACTH. Semiquantitative reverse transcriptase-PCR demonstrated that both $\mathrm{CRH}$ and CRH-BP mRNA obtained from the hippocampi of ACTHinjected infant rats was significantly depressed relative to salineinjected animals. Comparable reductions in both $\mathrm{CRH}$ and CRH-BP synthesis were further demonstrated with radioimmunoassay. In contrast, neither CRH-R1 nor CRH-R2 mRNA was
\end{abstract}

altered by ACTH treatment, relative to saline-injected rats. This latter finding was confirmed electrophysiologically by measuring the enhancement of hippocampal population spikes by exogenous CRH, also showing no differences between ACTH- and saline-injected rats. The results of this study support the proposal that systemic ACTH treatment down-regulates CRH expression in infant brain, perhaps contributing to the therapeutic efficacy observed during treatment of infantile spasms. (Pediatr Res 55: 604-610, 2004)
Abbreviations
aCSF, artificial cerebrospinal fluid
ACTH, adrenocorticotropic hormone
CRH, corticotropin-releasing hormone
CRH-BP, corticotrophin-releasing hormone-binding protein
CRH-R1, corticotropin-releasing hormone-receptor 1
CRH-R2, corticotropin releasing hormone-receptor 2
RT-PCR, reverse transcriptase-PCR

Adrenocorticotropic hormone (ACTH) is a 39 -amino acid peptide released into circulation by the anterior pituitary in response to corticotropin-releasing hormone $(\mathrm{CRH})$ stimulation from the hypothalamic paraventricular nuclei (1). Among its various physiologic effects, ACTH is known to regulate

Received February 21, 2003; accepted November 20, 2003.

Correspondence: Douglas D. Fraser, M.D., Ph.D., FRCPC, Paediatric Critical Care Unit, Children's Hospital of Western Ontario, 800 Commissioners Road East, London, Ontario, Canada, N6C 2V5; e-mail: fraserd@lhsc.on.ca

Financial support to D.D.F. includes Queen's University (Botterell Foundation, Advisory Research Council, and Angada Foundation), the Savoy Foundation for Epilepsy Research, and the Physicians' Services Incorporated Foundation.

DOI: 10.1203/01.PDR.0000112105.33521.DC both stress and immune responses via stimulation of the adrenal glands (2). In neonates, the adrenal glands are relatively insensitive to ACTH stimulation, and corticosterone release occurs primarily via constitutive secretion (3). Although this period of adrenal hyporesponsiveness is proposed to be protective under normal circumstances (4), excessive activity of the hypothalamic-pituitary axis (i.e. $\mathrm{CRH}$ release) may result in an attempt to elevate circulating levels of adrenal steroids after stressful events $(1,5)$. Excess synthesis and release of CRH during the neonatal period may also have detrimental effects on neuronal excitability and development during infancy (6).

Infantile spasms are an age-dependent epileptic syndrome associated with developmental delay and hypsarrhythmia (7). 
The cause of infantile spasms has been attributed to a wide variety of brain insults occurring during antenatal/perinatal development $(1,8)$. At present, infantile spasms are treated primarily with systemic ACTH administration. It is proposed that ACTH suppresses endogenous release of the excitatory neuropeptide CRH via a negative feedback mechanism $(1,9)$. $\mathrm{CRH}$ is elevated during periods of physiologic stress [i.e. antenatal and/or perinatal insults (10)] and possesses considerable convulsant activity if injected into the CNS of immature rats (6). These observations have led to the hypothesis that $\mathrm{CRH}$ is an endogenous convulsant in infant brain tissue, secondary to stress-induced alterations in the brain-adrenal axis. The alterations in the CRH system [CRH, CRH-binding protein (CRH-BP), and/or CRH receptors] by ACTH treatment, however, are unknown. Identification of the cellular mechanisms underlying ACTH modulation of the $\mathrm{CRH}$ system may allow for the development of novel therapeutic agents for the treatment of infantile spasms (i.e. CRH receptor antagonists).

The aim of this study, therefore, was to determine whether systemic ACTH therapy down-regulates the CRH system. More specific, we measured the expression levels of $\mathrm{CRH}$, CRH-BP, and CRH receptors (CRH-R1 and/or CRH-R2) using reverse transcriptase-PCR (RT-PCR), RIA and, electrophysiologic techniques. The data for this study were obtained from rats that were killed on postnatal day 10 . This age was specifically investigated as postnatal days $10-13$ are reported to correspond with human infancy based on similarities in synaptic maturation, myelination, and evolving expression of receptor and second messenger systems $(11,12)$. The hippocampus was chosen for study as previous investigations, both in vivo (6) and in vitro (13-16), have shown that this structure is responsive to $\mathrm{CRH}$ application. The data presented in this study support the hypothesis that systemic ACTH administration alters the nonhypothalamic $\mathrm{CRH}$ system and may contribute to the therapeutic efficacy of ACTH treatment of infantile spasms.

\section{METHODS}

All animal studies in this report have been approved by the Queen's University Institutional Review Board in accordance with the Guidelines of the Canadian Council on Animal Care.

Systemic ACTH administration. ACTH was dissolved in $0.9 \%$ saline, and $\sim 100 \mu \mathrm{L}$ was injected into rats (i.p.) at a dosage of $0.5 \mathrm{mg} \cdot \mathrm{kg}^{-1} \cdot \mathrm{d}^{-1} \cdot(17)$. The injections were performed at $1100 \mathrm{~h}$ for 7 consecutive days (postnatal days 3-9). Rats were killed under ketamine anesthesia on postnatal 10 , and blood was subsequently withdrawn from the left ventricle of the heart. Rat blood was immediately centrifuged to isolate serum. After the collection of blood samples, rats were decapitated and hippocampi were collected and stored in $1.5-\mathrm{mL}$ Eppendorf tubes at $-80^{\circ} \mathrm{C}$. Control rats received an i.p. injection daily with the same volume of $0.9 \%$ saline.

Serum corticosterone RIA. An RIA kit was used to determine corticosterone levels in rat blood serum (Diagnostic Products Corporation, Los Angeles, CA, U.S.A.). Briefly, 50 $\mu \mathrm{L}$ of blood serum from control or ACTH-treated rats was incubated with $1.0 \mathrm{~mL}$ of ${ }^{125} \mathrm{I}$-rat corticosterone in precoated tubes with antibody to rat corticosterone for $2 \mathrm{~h}$ at room temperature. After incubation, the solution was decanted and radioactivity was counted for $1 \mathrm{~min}$ in a gamma counter.

$\boldsymbol{R T}$-PCR. Total RNA isolation and RT-PCR were performed as previously described (18). Briefly, total RNA was obtained from the isolated CA1 region of rat hippocampus by the acid guanidinium thiocyanate-phenol-chloroform method (19). One microgram of total RNA was reverse transcribed by the AMV reverse transcriptase. The reaction was performed in the absence of reverse transcriptase or RNA as negative controls. For amplification of cDNA, an aliquot of reverse transcription mixture $(2.0 \mu \mathrm{L})$ was amplified with the following cycle parameters: $94^{\circ} \mathrm{C}$ for $45 \mathrm{~s}, 55^{\circ} \mathrm{C}$ for $45 \mathrm{~s}$, and $72^{\circ} \mathrm{C}$ for $90 \mathrm{~s}$. After 28 and 26 ( $\beta$-actin) cycles of amplification, a final extension cycle was performed at $72^{\circ} \mathrm{C}$ for $5 \mathrm{~min}$. PCR products were visualized by electrophoresis using a $1.5 \%$ agarose gel containing ethidium bromide. A negative control was performed using PCR amplification without cDNA. No products were detected from these control experiments. Kinetic studies of each gene were performed to give a linear range of amplification before semiquantitative analysis. PCR products obtained under the linear range were analyzed and visualized. A photograph of the gel was scanned in reflectance mode using computer-assisted linear scanning densitometer (DigitizerMatrox IM 1280). The optical intensities of the PCR products were quantified and analyzed by the software package MCID M2 (Imaging Research Inc.). The data were expressed as mean \pm SE. Differences between groups were compared by ANOVA or by Kruskal-Wallis one-way ANOVA on ranks using SigmaStat software (Jandel Scientific).

The primers chosen to assess mRNA were as follows: $\mathrm{CRH}$ (360 bp) 5'-CAA CTT TTT CCG CGT GTT GCT-3' and 5'-ATG GCA TAA GAG CAG CGC TAT-3'; CRH-R1 (476 bp) 5'-ACA AAC AAT GGC TAC CGG GAG-3' and 5'-ACA CCC CAG CCA ATG CAG AC-3'; CRH-R2 (615 bp) 5'-TGT GGA AGG CTG CTA CCT G-3' and 5'-GTC TGC TTG ATG CTG TGG AA-3'; CRH-BP (229 bp) 5'-TAC GAC CCT TTC CTG CTT TTC AGC-3' and 5'-GAA ATC CCC ACC CTG GCA GTC GAT-3'; $\beta$-actin (340 bp) 5'-CAA GAG ATG GCC ACG GCT GCT-3' and 5'-TCC TTC TGC ATC CTG TCG GCA-3'. The oligonucleotide primers were synthesized in the Department of Biochemistry at Queen's University.

RIA for CRH and CRH-BP. CRH RIA was performed using protocols and reagents from IgG Corp. (Nashville, TN, U.S.A.) as described previously $(18,20)$. Briefly, tissue lysates $(100 \mu \mathrm{L})$ were incubated with $100 \mu \mathrm{L}$ of primary antibodies (1:100, IgG-hCRH; IgG Corp.) for $3 \mathrm{~d}$ at $4{ }^{\circ} \mathrm{C}$. Then ${ }^{125} \mathrm{I}-\mathrm{Tyr}-$ hCRH (DuPont NEN, Boston, MA, U.S.A.) in $100 \mu \mathrm{L}$ of RIA buffer was added and incubated for another $2 \mathrm{~d}$ at $4^{\circ} \mathrm{C}$. A total of $100 \mu / \mathrm{L}$ of anti-rabbit $\gamma$-globulin serum was then added and incubated for $4 \mathrm{~h}$ at $4^{\circ} \mathrm{C}$, followed by adding $1.6 \mathrm{~mL}$ of ice-cold separation buffer (Phosphate-EDTA containing 2.5\% BSA) to dilute trace ${ }^{125} \mathrm{I}-\mathrm{hCRH}$ not bound to antibody. The reaction tubes were centrifuged at $6000 \times \mathrm{g}$ for $20 \mathrm{~min}$ at $4^{\circ} \mathrm{C}$, and supernatants were decanted. The pellets were counted using a gamma counter. CRH-BP RIA was performed as previously reported $(12,15)$. Briefly, tissue lysates were incubated with ${ }^{125}$ I-Tyr-hCRH (DuPont NEN) in assay buffer for $60 \mathrm{~min}$ at 
room temperature. CRH-BP antibody 5144 (provided by Dr. W. Vale, Salk Institute, San Diego, CA, U.S.A.) was then added at 1:1000 dilution, and the reaction was incubated overnight at room temperature. Bound complexes were precipitated by the addition of $200 \mu \mathrm{L}$ of anti-rabbit $\gamma$-globulin serum and incubated for $60 \mathrm{~min}$ at room temperature. After separation by centrifugation, antibody-bound ${ }^{125} \mathrm{I}-\mathrm{CRH}$ precipitate was then measured using a gamma counter.

Hippocampal slice preparation. Postnatal day 10 rats were decapitated, and the brain was immersed in chilled artificial cerebrospinal fluid (aCSF) containing (in $\mathrm{mM}$ ) $126 \mathrm{NaCl}, 2.5$ $\mathrm{KCl}, 2 \mathrm{MgCl}_{2}, 2 \mathrm{CaCl}_{2}, 1.25 \mathrm{NaH}_{2} \mathrm{PO}_{4}, 26 \mathrm{NaHCO}_{3}{ }^{-}$, and 10 D-glucose (pH 7.3) $(22,23)$. The hippocampi were isolated, sectioned perpendicular to their septotemporal axis $(400 \mu \mathrm{m})$, and incubated in aCSF oxygenated with $5 \% \mathrm{CO}_{2} / 95 \% \mathrm{O}_{2}$ at room temperature for a minimum of $1 \mathrm{~h}$ before experimentation.

Extracellular field recording. Hippocampal slices were individually transferred to a recording chamber mounted on a dissecting microscope and submerged in rapidly flowing (1 $\mathrm{mL} / \mathrm{min})$ oxygenated aCSF $\left(34^{\circ} \mathrm{C}\right)$. Extracellular recording micropipettes $(\sim 10 \mathrm{mOhms})$ were pulled from $1.5-\mathrm{mm}$ outer diameter thin-walled glass (150F-4, World Precision Instruments) in two stages on a Narishige puller (PP-83; Tokyo, Japan) and filled with $2 \mathrm{M} \mathrm{NaCl}$. A three-dimensional micromanipulator was used to position the recording electrode and a silver wire coated with $\mathrm{AgCl}$ connected the recording micropipette to an amplifier probe (Axoclamp-2A, Axon Instruments). The voltage output was monitored with an on-line oscilloscope, and amplified signals were digitized with pCLAMP software (Axon Instruments). A concentric, bipolar stimulating electrode (Rhodes Electronics) was placed on the Schaffer collaterals to elicit field potentials recorded in the CA1 cell body layer (stratum pyramidale). Field potentials were evoked with an S88 Grass square pulse stimulator connected to a Grass SIU6 stimulation isolation unit. Pulses $(0.2 \mathrm{~ms}$ duration; 0.3 $\mathrm{Hz}$ ) were applied at $10-$ to $30-\mathrm{mV}$ intensities. The voltage depended on the intensity required to produce a one-half maximal population spike. A calibrator connected between the bath and the ground generated a $1-\mathrm{mV}, 5-\mathrm{ms}$ control pulse. Digitized data were signal-averaged and analyzed using a PC computer with pCLAMP software (Axon Instruments). Population spike amplitude was determined by measuring the difference between the first positive deflection after the stimulation artifact and the maximal negative deflection. Statistical significance was determined with a $t$ test.

\section{RESULTS}

Rat pup littermates were randomly divided into ACTH- or saline-treated groups on postnatal day 3. After i.p. injection of either ACTH or saline for 7 consecutive days, the animals were killed on postnatal day 10 and serum corticosterone levels were determined by RIA. As shown in Figure 1, serum corticosterone levels were increased $\sim 20$-fold in the ACTH-treated group as compared with the saline group ( $p<0.001, n=27$ /group). These results are consistent with previous reports $(17,24)$ indicating that i.p. ACTH is absorbed systemically and in-

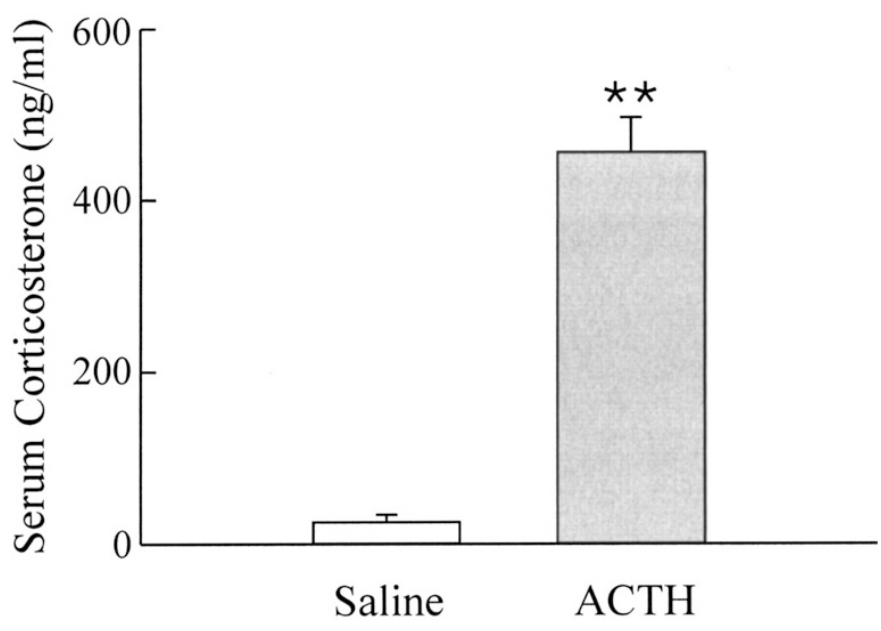

Figure 1. Serum corticosterone levels obtained from saline- and ACTHtreated infant rats. A plot demonstrating the mean serum levels of corticosterone obtained from either saline- or ACTH-injected infant rats. The rats were killed after 7 consecutive days of i.p. treatment (ACTH or saline), and blood was removed via the left ventricle under ketamine anesthesia. Under these conditions, the ACTH-treated group demonstrated an $\sim 20$-fold increase in serum corticosterone levels $(* * p<0.001)$.

creases corticosterone levels in infant rats via adrenal stimulation.

Semiquantitative RT-PCR was performed to measure hippocampal mRNA levels for CRH and CRH-BP after treatment with ACTH or saline. In these experiments, specific primers for CRH (360 bp) and CRH-BP (229 bp) produced single bands of predicted size on agarose gel (18), demonstrating that both mRNAs are expressed in infant rat hippocampus. For determining whether these genes are regulated by treatment with $\mathrm{ACTH}$, total RNA was isolated from hippocampi on postnatal day 10 after 7 consecutive days of i.p. injection of either ACTH or saline. Semiquantitative RT-PCR using $\beta$-actin as an internal standard revealed that the levels of mRNA coding for CRH ( $\downarrow 34 \%)$ and CRH-BP $(\downarrow 26 \%)$ were significantly depressed in the ACTH-treated groups relative to saline controls $(p>0.05$, $n=27$ /group; Fig. 2).

For further determining the effect on CRH and CRH-BP production after a 7-d treatment with ACTH, RIA for CRH and CRH-BP was performed as described previously (18-21). Consistent with the decreased expression of mRNA for CRH and CRH-BP, treatment with ACTH also resulted in decreased levels of both CRH ( $\downarrow 39 \%)$ and CRH-BP ( $\downarrow 30 \% ; p>0.05$, $n=27$ /group; Fig. 3).

Semiquantitative RT-PCR was also used to measure hippocampal mRNA levels for CRH-R1 and CRH-R2 after treatment with either ACTH or saline. In these experiments, specific primers for CRH-R1 (476 bp) and CRH-R2 (615 bp) produced single bands of predicted size on agarose gel (18), demonstrating that both receptors are expressed in infant rat hippocampus. Semiquantitative RT-PCR using $\beta$-actin as an internal standard revealed that the levels of mRNA coding for CRH-R1 and CRH-R2 were not significantly down-regulated by ACTH treatment ( $n=27$ /group; Fig. 4 ).

These latter data were further supported by electrophysiologic studies demonstrating that the $\mathrm{CRH}$-induced excitation 


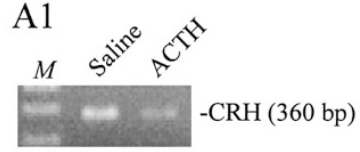

A2

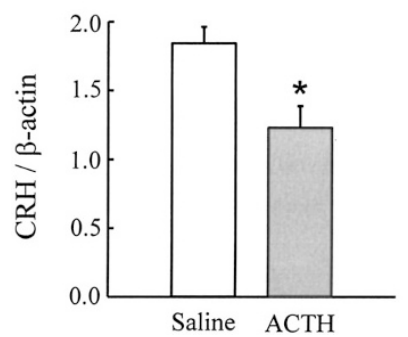

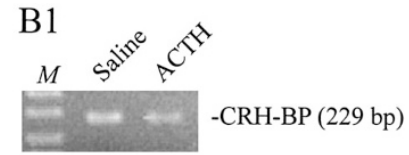

B2

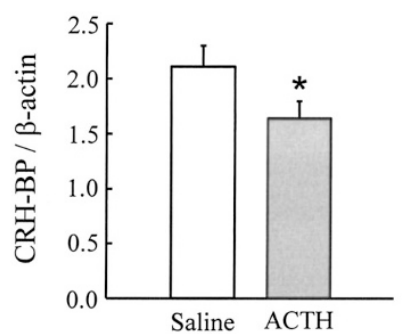

Figure 2. Expression of $\mathrm{CRH}$ and $\mathrm{CRH}-\mathrm{BP}$ mRNA from hippocampus obtained from either saline- or ACTH-treated infant rats. $(A)$ RT-PCR of CRH (360 bp) obtained form saline- and ACTH-treated infant rats for 28 amplification cycles. The band corresponding to $\mathrm{CRH}$ from a saline-treated animal is of much greater intensity than the $\mathrm{CRH}$ band from the ACTH-treated animal, indicating ACTH down-regulated $\mathrm{CRH}$ mRNA expression in infant rat hippocampus. Also illustrated is a plot demonstrating the mean decrease in $\mathrm{CRH}$ mRNA expression between groups $(* p<0.05)$. The CRH mRNA expression was significantly depressed in the ACTH-treated animals. (B) RT-PCR of CRH-BP (229 bp) obtained form saline- and ACTH-treated infant rats for 28 amplification cycles. The band corresponding to $\mathrm{CRH}-\mathrm{BP}$ from a saline-treated animal is of much greater intensity than the CRH-BP band from the ACTHtreated animal, indicating ACTH down-regulated CRH-BP mRNA expression in infant rat hippocampus. Also illustrated is a plot demonstrating the mean decrease in CRH-BP mRNA expression between groups $\left({ }^{*} p<0.05\right)$. The CRH-BP mRNA expression was significantly depressed in the ACTH-treated animals.

A

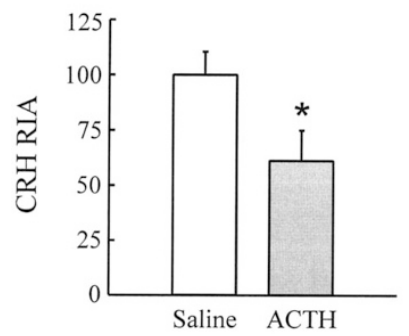

B

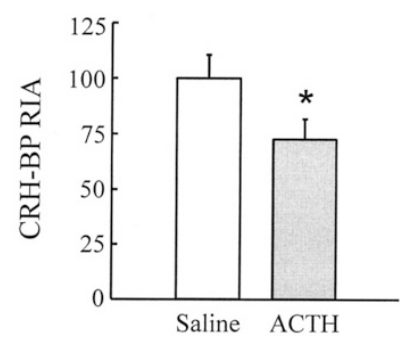

Figure 3. Expression levels of $\mathrm{CRH}$ and $\mathrm{CRH}-\mathrm{BP}$ in hippocampus obtained from either saline- or ACTH-treated infant rats. (A) RIA for CRH was performed with a peptide-specific antibody (IgG-hCRH). A plot is shown demonstrating the mean decrease in $\mathrm{CRH}$ expression in the ACTH-treated animals $\left({ }^{*} p<0.05\right)$. (B) RIA for CRH-BP was performed with a peptidespecific antibody (CRH-BP antibody 5144). A plot is shown demonstrating the mean decrease in $\mathrm{CRH}$ expression in the $\mathrm{ACTH}$-treated animals $\left({ }^{*} p<0.05\right)$.

was not altered in ACTH-treated animals relative to saline controls. In noninjected infant rats, the population spike amplitude recorded in the CA1 region of the hippocampus was reversibly enhanced by the bath application of $200 \mathrm{nM} \mathrm{CRH}$ ( $\uparrow$ by $108 \pm 4 \% ; n=14$; Fig. $5 A$ ). Although seizure-like activity was not observed after CRH application, epileptiform activity likely requires intact limbic circuitry not present in the de-afferented hippocampal slice preparation. The observed increase in hippocampal population spike amplitude elicited by $\mathrm{CRH}$ occurred via stimulation of $\mathrm{CRH}-\mathrm{R} 1$, the dominant $\mathrm{CRH}$
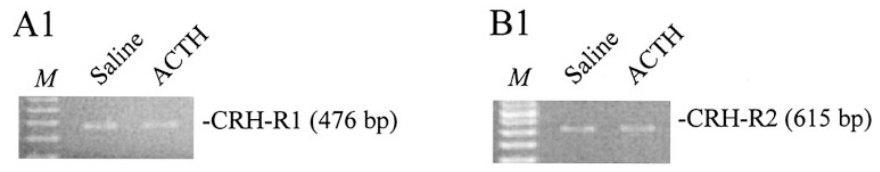

A2

B2
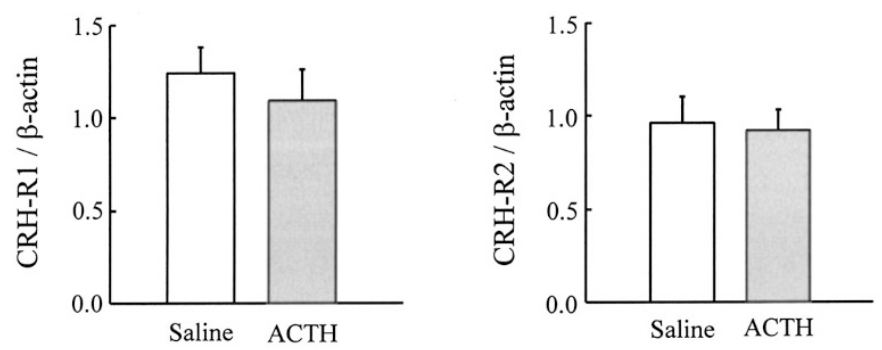

Figure 4. Expression of CRH-R1 and CRH-R2 mRNA in hippocampus from saline- and ACTH-treated infant rats. (A1) RT-PCR of CRH-R1 (476 bp) obtained from saline- and ACTH-treated infant rats after 28 amplification cycles. The band corresponding to CRH-R1 from a saline-treated animal is of similar intensity to the CRH-R1 band from the ACTH-treated animal, indicating that ACTH did not down-regulate CRH-R1 mRNA expression in infant rat hippocampus. (A2) A plot demonstrating the similar expression levels of CRH-R1 mRNA expression between groups (*p<0.05). (B1) RT-PCR of CRH-R2 (615 bp) obtained form saline- and ACTH-treated infant rats for 28 amplification cycles. The band corresponding to CRH-R2 from a saline-treated animal is of similar intensity to the CRH-BP band from the ACTH-treated animal, indicating that ACTH failed to down-regulate CRH-R2 mRNA expression in infant rat hippocampus. (B2) A plot demonstrating the similar expression levels of CRH-R2 mRNA between groups $(* p<0.05)$.

receptor expressed in infant rat hippocampus. Indeed, the expression of CRH-R1 mRNA was 12-fold greater than the CRH-R2 mRNA ( $n=3$ animals/group, $p<0.001$; Fig. $5 A$ ), and the selective CRH-R1 receptor antagonist antalarmin competitively inhibited the $\mathrm{CRH}$-induced enhancement of population spikes $(\mathrm{CRH}$ alone $\uparrow 102 \pm 11 \%$; CRH $+100 \mathrm{nM}$ antalarmin $\uparrow 50 \pm 14 \%, n=10, p<0.05 ; \mathrm{CRH}+500 \mathrm{nM}$ antalarmin $\uparrow 9 \pm 9 \%, n=10, p<0.001$; Fig. 5). Application of $200 \mathrm{nM} \mathrm{CRH}$ to either ACTH- or saline-treated animals resulted in enhancement of the population spike amplitudes that did not significantly differ between groups (ACTH, $\uparrow$ to $67 \pm 17 \%, n=10$; Saline $\uparrow$ to $72 \pm 3 \%, n=10 ; p=0.94)$. These final experiments illustrate that systemic ACTH treatment did not alter CRH receptor-mediated responses (particularly CRH-R1) to exogenous CRH.

\section{DISCUSSION}

This study demonstrates that systemic administration of ACTH decreases the expression of both CRH and CRH-BP in infant rat hippocampus. Neither CRH-R1 nor CRH-R2 was altered by the ACTH therapy. These data support the hypothesis that ACTH treatment reduces the activity of the CRH system in infant brain and that specific down-regulation of CRH synthesis may underlie the clinical efficacy of this therapy in the treatment of infantile spasms.

We have demonstrated that $\mathrm{ACTH}$ treatment down-regulates the expression of CRH mRNA and protein in the infant rat hippocampus. CRH-containing neurons have been identified throughout the limbic system $(25,26)$, and stress-induced 
A

Non-injected animals
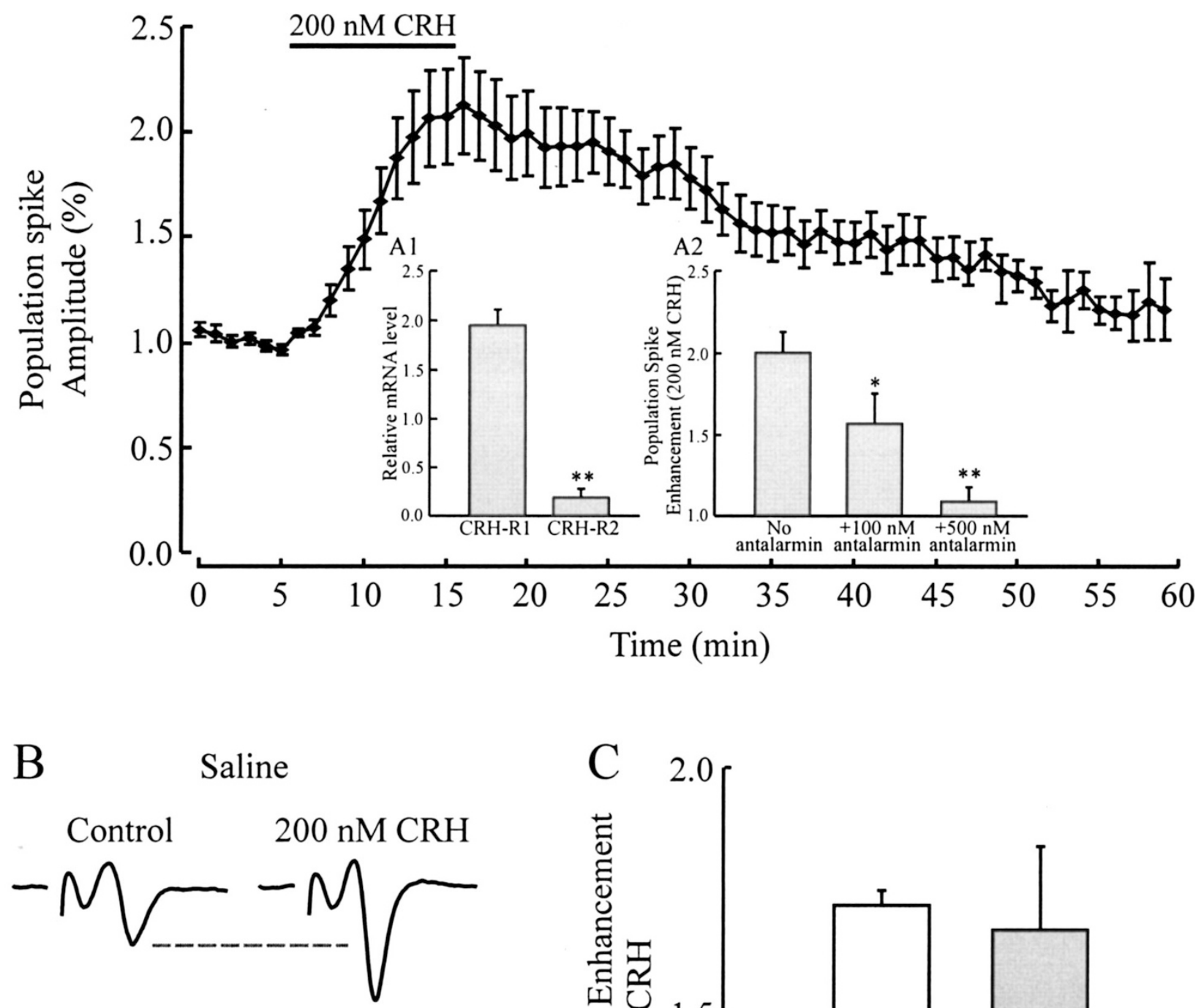

$\mathrm{ACTH}$
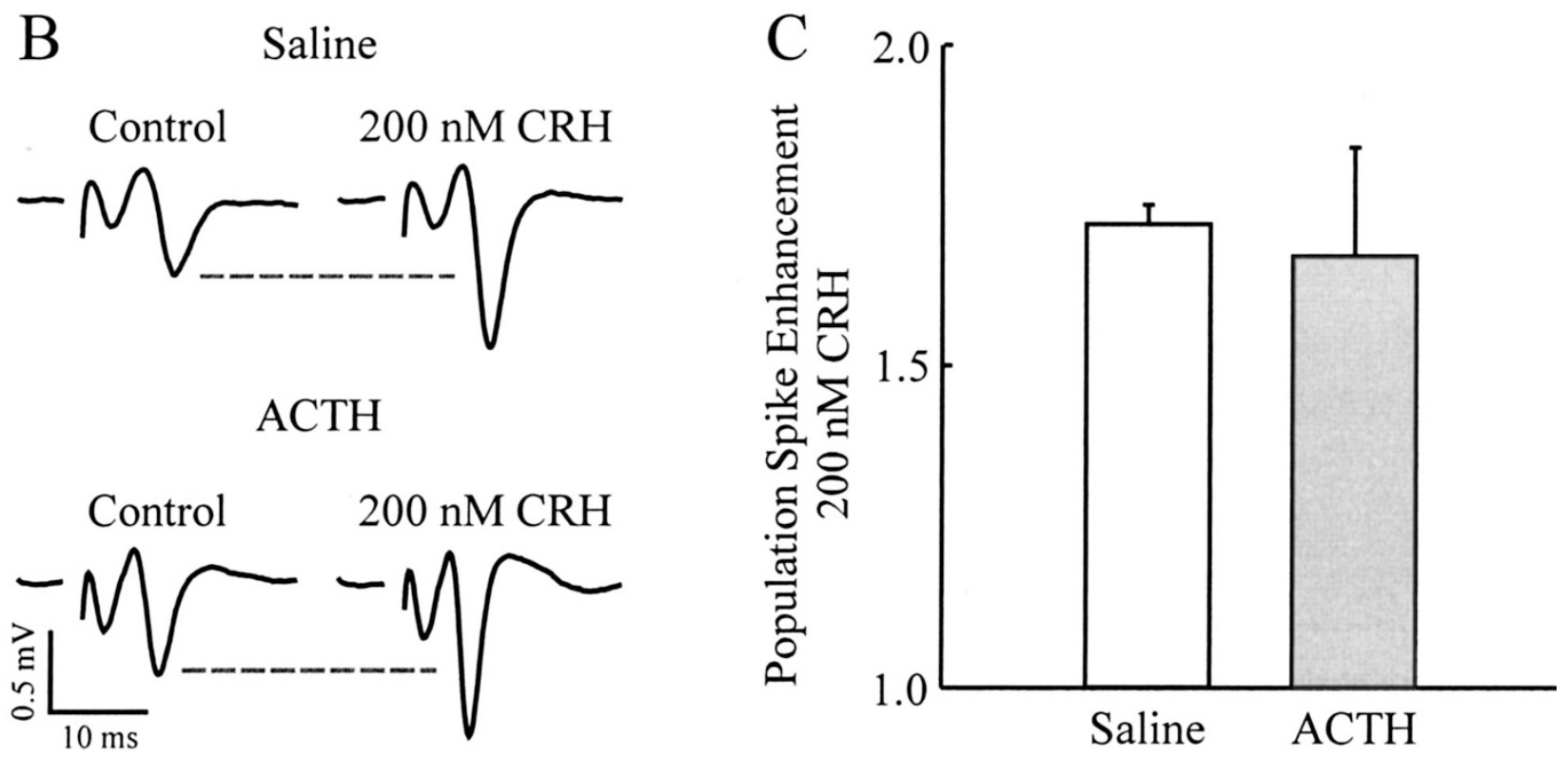

Figure 5. Electrophysiologic recordings demonstrate no change in the CRH-mediated increases in population spike amplitude in saline- and ACTH-treated infant rats. (A) A plot demonstrating the time course of the population spike enhancement in the CA1 region of infant rat hippocampal slice by $200 \mathrm{nM}$ CRH. The data were normalized to $100 \%(n=14)$. (Al) Relative CRH receptor mRNA expression levels in the infant rat hippocampus (CA1 region) as determined by RT-PCR $(* * p<0.001)$. (A2) Inhibition of CRH-induced increases in population spike amplitude by a selective CRH-R1 antagonist $(* p<0.05 ; * * p<0.001)$. $(B)$ A control population spike recorded in CA1 stratum pyramidale after stimulation of the Schaffer collaterals. The population spike was reversibly enhanced by a 10-min perfusion with $200 \mathrm{nM} \mathrm{CRH}$ in both saline- and ACTH-treated animals. (C) A plot demonstrating the population spike enhancement by $200 \mathrm{nM}$ $\mathrm{CRH}$ in both saline- and ACTH-treated animals. The data were normalized to $100 \%(p=0.94)$.

release of $\mathrm{CRH}$ from limbic structures has been measured using microdialysis $(27,28)$. Increased expression of $\mathrm{CRH}$ is elicited by seizure activity (29-31), and CRH synthesis is chronically elevated in postmortem brain obtained from children with generalized epilepsy (18). Application of CRH to tissue slices increases neuronal excitability $(13-16,32,33)$, whereas intracerebroventricular injection of $\mathrm{CRH}$ elicits electroencephalographic and behavioral seizures $(34,35)$. These data implicate $\mathrm{CRH}$ as an endogenous convulsant in the developing brain $(1,6)$ and support the hypothesis that $\mathrm{ACTH}$ has 
anticonvulsant actions by down-regulation of $\mathrm{CRH}$ synthesis and release (1).

In contrast to our findings, a recent in situ hybridization study reported that exogenous ACTH administration downregulates CRH mRNA expression specifically in the amygdala and that hippocampal CRH mRNA was not altered (9). The differences between studies might be explained by the duration of ACTH treatment. For example, we injected animals with ACTH for 7 consecutive days, as opposed to a single high-dose ACTH injection $4 \mathrm{~h}$ before mRNA analysis (9). In support of this argument, the same study (9) showed that elevating endogenous ACTH levels $>2$-fold for $24 \mathrm{~h}$ via adrenalectomy also decreased the expression of hippocampal CRH mRNA. Inhibition of CRH expression by ACTH therefore may be less sensitive in the hippocampus, an area devoid of ACTHcontaining fibers (36), unlike the amygdala. It is also possible that chronic ACTH therapy inhibits not only $\mathrm{CRH}$ production but also the number of hippocampal $\mathrm{CRH}$-expressing neurons that are transiently present during development (37).

The CRH-BP is coexpressed in structures with significant CRH immunostaining (38), and CRH-BP regulates the bioavailability of CRH (39). Both coordinate and divergent alterations in CRH and CRH-BP expression have been reported, and the biologic actions of CRH may be limited by steroidinduced expression of CRH-BP (40). The down-regulation of $\mathrm{CRH}$ in this study was accompanied by a similar reduction in the CRH-BP expression. Parallel changes in both CRH and CRH-BP expressions have been observed in animals after kainate-induced seizures (29), and we have previously demonstrated that both CRH and CRH-BP expression are chronically elevated in postmortem brain obtained from children with generalized epilepsy (18).

The CRH receptor subtypes have been cloned, characterized, and classified as either CRH-R1 or CRH-R2 (41). Our competitive RT-PCR experiments demonstrated that mRNA for both CRH-R1 and CRH-R2 receptors are expressed in the infant rat CA1 region, although the mRNA for CRH-R1 is expressed at a 12-fold higher level than CRH-R2. The CRHinduced increase in population spike amplitude shown here was also dependent on CRH-R1 stimulation. Systemic administration of ACTH did not alter the expression levels of either CRH-R1 or CRH-R2 and did not alter the CRH-induced increase in population spike amplitude mediated by CRH-R1. The ACTH modulation of the CRH system therefore is confined to reductions in CRH and CRH-BP expression.

The down-regulation of hippocampal CRH may involve the chronic stimulation of melanocortin receptors (MC1-R to MC4-R) by ACTH $(9,42)$. In the amygdala, selective blockade of MC4-R prevents ACTH-induced down-regulation of $\mathrm{CRH}$ expression (9), suggesting that ACTH acts directly on the amygdala and is independent of adrenal steroidogenesis. MC4-R is also expressed in the hippocampus (43) and binds ACTH with high affinity (44). The link between ACTH stimulation of hippocampal MC4-R and subsequent inhibition of $\mathrm{CRH}$ expression has not been determined.

Elevated adrenal corticosterone was observed in our study and may have contributed to the ACTH-induced inhibition of hippocampal CRH expression. During development, cortico- steroid receptors are highly expressed in the hippocampus, and activation of these receptors modulates a variety of cellular responses, including intrinsic metabolism, neurogenesis, neuronal migration, and cell death $(45,46)$. In electrophysiologic studies, corticosteroids depress neuronal excitability by reducing repetitive action potential firing, enhancing the inhibitory actions of serotonin, and altering long-term synaptic facilitation (47). Endogenous corticosteroid levels are chronically elevated after treatment with the ketogenic diet, a clinically efficacious therapy for a variety of childhood intractable epilepsies (48). Exogenous corticosteroids have been used both in the treatment of infantile spasms (albeit less effectively than $\mathrm{ACTH})(49,50)$ and as empiric treatment for a variety of childhood epilepsies $(51,52)$.

Alternative explanations have been proposed for the efficacy of ACTH treatment of infantile spasms. For example, ACTH controls the synthesis of deoxycorticosterone, a mineralocorticoid precursor that is enzymatically converted to a bioactive neurosteroid, tetrahydrodeoxycorticosterone (THDOC) (53). These deoxycorticosterone-derived neurosteroids modulate GABA receptor function and seizure susceptibility (54). The therapeutic actions of ACTH may result from multiple mechanisms that balance excessive $\mathrm{CRH}$-induced excitation and inadequate GABAergic inhibition. For example, application of $\mathrm{CRH}$ to hippocampal slices suppresses the amplitude of evoked inhibitory postsynaptic currents mediated by GABA (15). The ACTH-induced down-regulation of $\mathrm{CRH}$, together with neurosteroid modulation of GABA receptor function, would significantly elevate GABAergic-mediated inhibition and restore the excitation-inhibition balance. It is interesting that the anticonvulsant Vigabatrin, a GABA transaminase inhibitor (55), results in significant elevations in circulating GABA and is equally efficacious to $\mathrm{ACTH}$ in the treatment of infantile spasms $(56,57)$.

Infantile spasms represent a devastating epileptic syndrome that rarely results in normal psychomotor development (8). Although the early identification of infantile spasms and ACTH treatment improves outcome, current treatment regimens are far from optimal. Given our poor understanding of the cellular mechanisms underlying ACTH treatment of infantile spasms, further research is warranted to develop improved therapeutic agents (i.e. $\mathrm{CRH}$ and/or MC receptor antagonists).

Acknowledgments. We thank Dr. W. Vale for CRH-BP antibody 5144, Dr. K. Rice for antalarmin, and Dr. P. Ji for technical assistance.

\section{REFERENCES}

1. Baram TZ 1993 Pathophysiology of massive infantile spasms: perspectives on the putative role of the brain adrenal axis. Ann Neurol 33:231-236

2. Ottaviani E, Franchini A, Genedani S 1999 ACTH and its role in immuneneuroendocrine functions. A comparative study. Curr Pharm Des 5:673-681

3. Arai M, Widmaier EP 1993 Steroidogenesis in isolated adrenocortical cells during development in rats. Mol Cell Endocrinol 92:91-97

4. Dallman MF 2000 Editorial: moments in time - the neonatal rat hypothalamopituitary-adrenal axis. Endocrinology 141:1590-1592

5. Vazquez DM 1998 Stress and the developing limbic-hypothalamic-pituitary-adrenal axis. Psychoneuroendocrinology 23:663-700

6. Baram TZ, Hatalski CG 1998 Neuropeptide-mediated excitability: a key triggering mechanism for seizure generation in the developing brain. Trends Neurosci 21:471476 
7. Gaza CC, Sankar R 1998 Pathogenesis of the developmental epilepsies. Curr Opin Pediatr 10:567-574

8. Watanabe K 1998 West syndrome: etiological and prognostic aspects. Brain Dev 20:1-8

9. Brunson KL, Khan N, Eghbal-Ahmadi M, Baram TZ 2001 Corticotropin (ACTH) acts directly on amygdala neurons to down-regulate corticotropin-releasing hormone gene expression. Ann Neurol 49:304-312

10. Smith R 1999 The timing of birth. Sci Am 3:68-75

11. Dobbing J, Sands J 1973 Quantitative growth and development of human brain. Arch Dis Child 48:757-767

12. Graham YP, Heim C, Goodman SH, Miller AH, Nemeroff CB 1999 The effects of neonatal stress on brain development: implications for psychopathology. Dev Psychopathol 11:545-565

13. Aldenhoff JB, Goul DM, Rivier J, Vale W, Siggins GR 1983 Corticotropin-releasing factor decreases postburst hyperpolarization and excites hippocampal neurons. Science 221:875-877

14. Smith B, Dudek FE 1994 Age-related epileptogenic effects of corticotropin-releasing hormone in the isolated CA1 region of rat hippocampal slices. J Neurophysiol $72: 2328-2333$

15. Hollrigel GS, Chen K, Baram TZ, Soltesz I 1998 The pro-convulsant actions of corticotropin-releasing hormone in the hippocampus of infant rats. Neuroscience 84:71-79

16. Haug T, Storm JF 2000 Protein kinase A mediates the modulation of the slow $\mathrm{Ca}^{2+}$-dependent $\mathrm{K}^{+}$current, $\mathrm{I}_{\mathrm{sAHP}}$, by the neuropeptides CRF, VIP and CGRP in hippocampal pyramidal neurons. J Neurophysiol 83:2071-2079

17. Alves SE, Akbari HM, Anderson GM, Azmitia EC, McEwen BC, Strand FL 1997 Neonatal ACTH administration elicits long-term changes in forebrain monoamine innervation. Subsequent disruptions in hypothalamic-pituitary-adrenal and gonadal function. Ann N Y Acad Sci 814:226-251

18. Wang W, Dow KE, Fraser DD 2001 Elevated corticotrophin releasing hormone/ corticotropin releasing hormone-R1 expression in postmortem brain obtained from children with generalized epilepsy. Ann Neurol 50:404-409

19. Chomczynski P, Sacchi N 1987 Single step method of RNA isolation by acid guanidinium thiocyanate-phenol-chloroform extraction. Anal Biochem 162:156-159

20. Mulchahey JJ, Regmi A, Sheriff S, Balasubramaniam A, Kasckow JW 1999 Coordinate and divergent regulation of corticotrophin-releasing factor (CRF) and CRFbinding protein expression in an immortalized amygdalar neuronal cell line. Endocrinology 140:251-259

21. Behan DP, Maciejewski D, Chalmers D, DeSouza EB 1995 Corticotropin releasing factor binding protein (CRF-BP) is expressed in neuronal and astrocytic cells. Brain Res 698:259-264

22. Fraser DD, MacVicar BA 1996 Cholinergic-dependent plateau potential in hippocampal CA1 pyramidal neurons. J Neurosci 16:4112-4128

23. Fraser DD, Doll D, MacVicar BA 2001 Serine/threonine protein phosphatases and synaptic inhibition regulate the expression of cholinergic-dependent plateau potentials. J Neurophysiol 85:1197-1205

24. Baram TZ, Shultz L 1995 ACTH does not control neonatal seizures induced by administration of exogenous corticotrophin-releasing hormone. Epilepsia 36:174-178

25. Sakanaka M, Shibasaki T, Lederis K 1987 Corticotropin releasing factor-like immunoreactivity in the rat brain as revealed by a modified cobalt-glucose oxidasediaminobenzidine. J Comp Neurol 260:256-298

26. Yan XX, Toth Z, Schultz L, Ribak CE, Baram TZ 1998 Corticotropin-releasing hormone (CRH)-containing neurons in the immature rat hippocampal formation: ligh and electron microscopic features and colocalization with glutamate decarboxylate and parvalbumin. Hippocampus 8:231-243

27. Pich EM, Lorang M, Yegeneh M, Rodriguez de Fonseca F, Raber J, Koob GF, Weiss F 1995 Increase of extracellular corticotropin-releasing factor-like immunoreactivity levels in the amygdala of awake rats during restraint stress and ethanol withdrawal as measured by microdialysis. J Neurosci 15:5439-5447

28. Merali Z, McIntosh J, Kent P, Michaud D, Anisman H 1998 Aversive and appetitive events evoke the release of corticotropin-releasing hormone and bombesin-like peptides at the central nucleus of the amygdala. J Neurosci 18:4758-4766

29. Smith MA, Weiss SR, Berry RL, Zhang LX, Clark M, Massenburg G, Post RM 1997 Amygdala-kindled seizures increase the expression of corticotropin-releasing factor (CRF) and CRF-binding protein in GABAergic interneurons of the dentate hilus. Brain Res 745:248-256

30. Piekut DT, Phipps B 1999 Corticotropin-releasing factor immunolabeled fibers in brain regions with localized kainate neurotoxicity Acta Neuropathol 98:622-628

31. Masui JS, Morinobu S, Takahashi Y, Tsunashima K, Noda A, Yamada N, Kato N 1999 Elevated neuropeptide Y and corticotropin-releasing factor in the brain of a novel epileptic mutant rat: Noda epileptic rat. Brain Res 833:286-290
32. Siggins GR, Groul D, Aldenhoff J, Pittman Q 1985 Electrophysiological actions of corticotropin-releasing factor in the central nervous system. Fed Proc 44:237242

33. Rannie DG, Fernhout JH, Schinnick-Gallagher P 1992 Differential actions of corticotropin-releasing factor on basolateral and central amygdaloid neurons, in vitro. J Pharmacol Exp Ther 263:846-858

34. Baram TZ, Shultz L 1991 Corticotropin-releasing hormone is a rapid and potent convulsant in the infant rat. Brain Res Dev Brain Res 61:97-101

35. Baram TZ, Ribak CE 1995 Peptide-induced infant status epilepticus causes neuronal death and synaptic reorganization. Neuroreport 6:277-280

36. Watson SJ, Richard CW III, Barchas JD 1978 Adrenocorticotropin in rat brain: immunocytochemical localization in cells and axons. Science 200:1180-1182

37. Chen Y, Bender RA, Frotscher M, Baram TZ 2001 Novel and transient populations of corticotrophin-releasing hormone-expressing neurons in developing hippocampus suggest unique functional roles: a quantitative spatiotemporal analysis. J Neurosci 21:7171-7181

38. Potter E, Behan DP, Linton EA, Lowry PJ, Sawchenko PE, Vale WW 1992 The central distribution of a corticotropin-releasing factor (CRF)-binding protein predicts multiple sites and modes of interaction with CRH. Proc Natl Acad Sci U S A 89:4192-4196

39. Behan DP, De Souza EB, Lowry PJ, Potter E, Sawchenko P, Vale WW 1995 Corticotropin releasing factor (CRF) binding protein: a novel regulator of $\mathrm{CRH}$ and related peptides. Front Neuroendocrinol 16:362-382

40. Mulchahey JJ, Regmi A, Sheriff S, Balasubramaniam A, Kasckow JW 1999 Coordinate and divergent regulation of corticotropin-releasing factor (CRF) and CRFbinding protein expression in an immortalized amygdalar neuronal cell line. Endocrinology 140:251-259

41. McCarthy JR, Heinrichs SC, Grigoriadis DE 1999 Recent advances with the CRF1 receptor: design of small molecule inhibitors, receptor subtypes and clinical indications. Curr Pharm Des 5:289-315

42. Adan RAH, Gispen WH 2000 Melanocortins and the barin: from effects via receptors to drug targets. Eur J Pharmacol 405:13-24

43. Mountjoy KG, Mortrud MT, Low MJ, Simerly RB, Cone RD 1994 Localization of the melanocortin-4 receptor (MC4-R) in neuroendocrine and autonomic control circuits in the brain. Mol Endocrinol 8:1293-1308

44. Adan RAH, Cone RD, Burbach JPH, Gispen WH 1994 Differential effects of melanocortin peptides on neural melanocortin receptors. Mol Pharmacol 46:11821190

45. De Kloet ER, Vreugdenhil E Oitzl MS, Joëls M 1998 Brain corticosteroid receptor balance in health and disease. Endocr Rev 19:269-301

46. Edwards HE, Burnham WM 2001 The impact of corticosteroids on the developing animal. Pediatr Res 50:433-440

47. Joëls M 2000 Modulatory actions of steroid hormones and neuropeptides on electrical activity in brain. Eur J Pharmacol 405:207-216

48. Fraser DD, Whiting S, Andrew RD, MacDonald EA, Musa-Veloso K, Cunnane SC 2003 Elevated polyunsaturated fatty acids in blood serum obtained from children on the ketogenic diet. Neurology 60:1026-1029

49. Snead OC III, Benton JW, Hosey LC, Swann JW, Spink D, Martin D, Rej R 1989 Treatment of infantile spasms with high-dose ACTH: efficacy and plasma levels of ACTH and cortisol. Neurology 39:1027-1031

50. Baram TZ, Mitchell WG, Tourney A, Snead OC, Hanson RA, Horton EJ 1996 High-dose corticotrophin (ACTH) versus prednisone for infantile spasms: a prospective, randomized, blinded study. Pediatrics 97:375-379

51. Prasad AN, Stafstrom CF, Holmes GL 1996 Alternative epilepsy therapies: the ketogenic diet, immunoglobulins, and steroids. Epilepsia 37:S81-S95

52. Sinclair DB 2003 Prednisone therapy in pediatric epilepsy. Pediatr Neurol 28:194198

53. Rogawski MA, Reddy DS 2002 Neurosteroids and infantile spasms: the deoxycorticosterone hypothesis. Int Rev Neurobiol 49:199-219

54. Reddy DS, Rogawski MA 2002 Stress-induced deoxycorticosterone-derived neurosteroids modulate $\mathrm{GABA}_{\mathrm{A}}$ receptor function and seizure susceptibility. J Neurosci 22:3795-3805

55. Taylor CP 1999 Mechanisms of new antiepileptic drugs. Adv Neurol 79:1011-1026

56. Koo B 1999 Vigabatrin in the treatment of infantile spasms. Pediatr Neurol 20:106 110

57. Dimova PS, Korinthenberg R 1999 Efficacy of lamotrigine and vigabatrin in drugresistant epilepsies of childhood. Pediatr Neurol 21:802-807 